\title{
HOW TO FOSTER FRUITFUL COLLABORATIONS - THE IMPACT OF SUSTAINABILITY SCIENCE
}

\author{
LARA BRUNGS, KATHARINA KÖTTER-LANGE, JANA KOTTMEIER, REBECCA POERSCH \& \\ PETRA SCHWEIZER-RIES \\ Lehr- und Forschungslabor Nachhaltige Entwicklung (LaNE, Teaching and Research Lab for \\ Sustainable Development), University of Applied Sciences Bochum, \\ Germany/Accompanying LaNE-Team Energiewendebauen.
}

\begin{abstract}
One of the most urgent topics of the present, yet only slowly and arduously proceeding, is the energy transition, especially in the heat and building sector. Here, the basic hypothesis is that collaborations between all stakeholders involved are crucial to accelerate the process. The opening of every individual towards the perspective of others and an overarching joint intention is needed. Working from a sustainability science perspective, it is argued that approaching the transition from inside the system will lead to a common ground for collective action. The authors' role as communication researchers and transformative scientists is embedded in the broader accompanying research for the energy transition in the building sector ('Energiewendebauen'). With this paper and authors' work within the broader research network, an attempt is made to open the minds for innovative ways of working and facilitating the shift between science and practice by fostering thriving collaborations applying communication and collaboration knowledge. For this purpose, a multitude of different methods are drawn upon, some of which will be presented in this paper with a special focus on Generative Scribing, which is an artistic approach established in the context of Theory U. Although the method might initially be perceived as being rather unusual by some people and the practicing of this new way of working and communicating might even be rejected by a few, first findings show that when this method is used, people are intuitively attracted and open up in the process.

Keywords: collaboration, energy transition, generative scribing, interdisciplinarity, sustainability science, Theory $U$, transdisciplinary, transformation, transformational science, transepistemic.
\end{abstract}

\section{INTRODUCTION}

Smart grids, fuel cells in electrical power systems, energy-efficiency retrofits - thanks to continuous research we do already have the solutions at hand, yet we struggle implementing them. One example demonstrating the tedious development of the energy transition related to the authors' specific project is Germany's refurbishment rate stagnating at $1 \%$ making it highly unlikely to reach the federal government's target of 'an almost climate-neutral building stock' until $2050[1,2]$. The energy transition plays a vital role in achieving the goals of the 2030 Agenda for Sustainable Development [3] and is a fundamental part of the 'great transformation' called for by the German Advisory Council on Global Change (WBGU) [4].

United Nations Development Programme (UNDP) [5] and many others [6, 7]. Even though positive developments have been realized since the adoption of the Sustainable Development Goals, the effort put into attaining them is still not sufficient as 'the world is not on track for achieving most of the 169 targets [...]' [8]. The transition of the energy system towards sustainability is considered as a 'wicked problem' [9], meaning that it is highly complex due to the numerous actions involved and the interconnectedness between them. This makes it nearly impossible to grasp in full detail or even to oversee it. Hence, we are convinced that there is an urgent need for transepistemic and transdisciplinary collaborations between science, practice, politics, and the society as a whole to stimulate the development and to tackle the challenges ahead. To establish the collaborations needed, it is suggested that inclusive, appropriately 
uncommon methods like Art of Hosting [10], Design Thinking [11], or Generative Scribing [12] can be used in order to engage ourselves in a 'generative dialog' [13] resulting in collective action and shared responsibility with the aim of mitigating the climate crisis.

\section{TRANSITION RESEARCH AND COMPLEX SYSTEMS APPROACHES}

A need for change towards sustainability on the local, regional, national, and global level, i.e. transformation/transition, has been voiced in varying contexts. In this paper, transformation and transition are used interchangeably. As Göpel, like others, has put it: '... when it comes to defining what constitutes a transition versus what constitutes transformation (...), there is not much difference' [14]. The field of study that focuses on this topic is referred to as transition research. The origins of this field can be traced back to the 1990s, and it has grown into '[...] a highly multi-, inter- and transdisciplinary field [...]' [15]. During the years, its development has been fuelled due to the rising awareness that new approaches are needed, so that complex societal challenges and their dynamics can be investigated and adressed by guiding the development of social systems [15]. At first, mainly socio-technical systems and the transitions happening in these have been analyzed, however this focus has been extended by incorporating societal systems in general [15]. The starting point of transition research is a 'persistent or wicked problem', of which the identification and understanding of key drivers and stabilizers within the system is aspired to [14]. In institutionalism theory, different stabilizers are examined as 'path dependencies' [14]. These are important for identifying processes in systems that impede change. From a complex systems perspective, it can be said that they inherit essential feedback loops [14].

There are many different approaches in transition research. One of the most popular frameworks within the socio-technical approach is the so-called multi-level perspective (MLP) [15]. It has been put forward by scientists aiming at synthesizing socio-technical systems and evolutionary economics [16]. According to Geels, it is a '[...] mid-range theory that conceptualizes overall dynamic patterns in socio-technical transitions' [17]. Within this framework, transitions are described as non-linear processes, which are the result of interactions between different levels and are defined as '[...] a shift from one regime to another regime' [17]. The MLP differentiates three levels, all of which consist of heterogenous elements called 'technological niche', 'socio-technical landscape', and 'socio-technical regime' [16]. The last one is the most important as the others are defined in relation to it [17]. It is made up of rules that serve as coordination and orientation tools for a social group such as shared beliefs, lifestyles, user practices, or legally binding contracts [17]. The first level is a place, in which small groups work on innovations that are different to dimensions of the regime and actors hope for the innovations to diffuse to regime level [17]. However, this is not an easy task, but once networks become larger and a 'dominant design' is the result of aligning learning processes, niches gain impetus [17]. The second level describes the broader context, which does not only include the technical and material background but also political ideologies, societal values, macro-economic patterns, etc. [17]. The MLP abolishes simple causalities and emphasizes 'circular causality' due to the absence of only one driver leading to transitions [17]. This underlines the systemic root in the second order cypernetics of this predominantly technological approach.

Göpel has put forward her own approach based on the MLP and the multi-phase concept, in which she emphasizes the importance of humans in transformation processes, as they are '[...] both subject and object of making history, how reality today shapes the imaginary of how reality could be in the future' [15]. She highlights that how people behave in the world 
is influenced by how they see it [14]. Meadows is of the same opinion and argues that "paradigms are the sources of systems' [18]. Göpel however refers to 'paradigm' as 'mind' and argues that it stresses the process of knowing rather than the idea itself. Mind expresses that 'the way that seeing and believing differently goes beyond an update of information. It also means changes in attention, consciousness, instinct, imagination, judgment, power, sense, spirit, and psyche' [14]. Göpel extents the MLP by linking it with this reflexive ontology and the multi-phase concept, which is helpful when looking for the best stage to implement deliberate change in complex systems [14]. She calls this concept 'radical incremental transformation' [14] and stresses that 'the source of intentional change is human thinking, feeling and acting' [14].

Our work is based on complex system's approaches, which try to advance the challenges arising due to the high complexity of 'wicked problems' like the energy transition in a holistic way, taking into account technological, economic, political, socio-cultural, and, not least, ecological dimensions, as well as the interactions between them [19, 20]. Systems are described as 'composed of multiple components of different types, both tangible and intangible. They include, for example, people, resources and services, as well as relationships, values, and perceptions' [21]. The system approach is also often explained by modern quantum theory. After Werner Heisenberg, this states that 'matter and energy [...] form in the end an inseparable whole. Not the material particles are decisive in the microcosm, but the effective fields between them' [22]. In other words, within a system (be it the energy sector, our society, or the whole world) equally important to the single components are the relationships between them [23]. The term 'emergence' describes the occurrence of properties of a system 'that are not given with [its] objects but result from their interactions' [24]. Therefore, it is important to consider the process as a whole, considering the individual as well as the relations between them.

\section{THE ENERGY TRANSITION AS A TRANSEPISTEMIC AND COLLABORATIVE TASK}

At first sight one might think that the energy transition is mainly dependent on technological innovations. However, as shown above, not only technological feasibility is relevant but also a variety of different factors from financial to socio-cultural ones and the most important aspect: the human being. People accepting and supporting the process are needed to realize the transformation successfully, sustainably, and healthily.

In order to break existing path-dependencies, equally indispensable in all factors is - more than the dissemination of knowledge - the collective will of people in different sections of society to collectively achieve our aim. The whole process of the energy transition is far too complex and multi-dimensional to be solved by singular disciplines. Each discipline may add one dimension to the view on the transition, but to get a full picture of what needs to be done, several perspectives are required including those of stakeholders outside science. It is here argued that it is important to overcome silo mentality and instead connect actors and expertise from the different parts of the 'system' energy transition. A sole focus on disciplinary thinking in fact omits truly innovative, creative, and - above all - holistic ideas by narrowing perspectives on crucial topics. If the energy transition is to be realized, recipients of new energy systems and all relevant societal members willing to participate must be recognized as fully legitimated to contribute to this process [25]. Experts not only build differing knowhow, but they also often experience varying layers of our society's shared reality and, as to our human nature, experience them differently. As everybody carries his or her own set of 
experiences of values and interests, it is a complex interplay that shapes our individual perceptions and ways of thinking and, evidently, also how we approach challenges and find solutions. For this reason, we pledge not only for inter- and transdisciplinary, but also for transepistemic collaborations [26]: including various ways of knowing into the joint effort to transform not only but also our energy system, e.g. practical knowing as well as various types of scientific knowledge.

These collaborations do not only allow the transfer of existing knowledge from science to practice, but they also facilitate the mutual generation of new knowledge. Real collaborations come about when people connect on a deep level working towards a mutual goal on which everybody can agree. To establish such collaborations, 'safe' spaces with an open communication need to be created, in which all participants are willing to be vulnerable and are, therefore, able to empathize with others [10]. Within this context of true collaborations, we are not led by the past, but are sensing the emerging future guiding us towards a shared intention [13].

\section{SUSTAINABILITY SCIENCE SUPPORTING TRANSEPISTEMIC COLLABORATIONS}

In this research within the larger project of the energy transition for the German building sector, the aim is to contribute with communication and collaboration knowledge from the sustainability science. Questions targeted are how can we create a safe space where people from different disciplinary cultures and also outside science can come together and open up to each other's realities and experiences? What might be the best approach to pave the way for socio-technical innovations in the form of societal and political acceptance, a window of opportunity, to be filled with new ideas? Which concepts are most suited to design our working spaces and communication processes for the development of connection and a shared intention? And how can we pool our expertise and efforts into what we call 'concerted action' and co-create a sustainability transformation?

Sustainability science, by nature, incorporates all research fields and dissolves disciplinary boundaries, not only between scientific disciplines but also between science, practice, politics, and the society as a whole. Sustainability science is transepistemic and transdisciplinary, value-oriented and normative, taking over responsibility and systemic [26, 27]. In addition, it can be seen as intendedly transformative [28] as well as consciousness based [27]. This kind of sustainability science is not only occupied with the analysis and description of transformation processes (transformation research) but also normatively fosters change itself (transformative science). This action research is accompanied by reflecting and learning processes [29] and deepening the consciousness not only of the subjects of research but also of the researchers themselves [27].

We as transformative and awareness-based sustainability scientists advocate for focusing on the deeper dimensions of individuals exploring the source of our actions [27] - the 'blind spot' as Scharmer calls it [13]. Scharmer and Käufer call this as 'awareness-based action research' [30]. In this kind of research, science does not only do research, but it also seeks to change with the society in the process [27].

\section{OUR ASSIGNMENT WITHIN THE PROJECT}

Our research team has been assigned with the task to promote transdisciplinary and transepistemic collaborations between the many different actors involved in the energy transition of the building sector. 


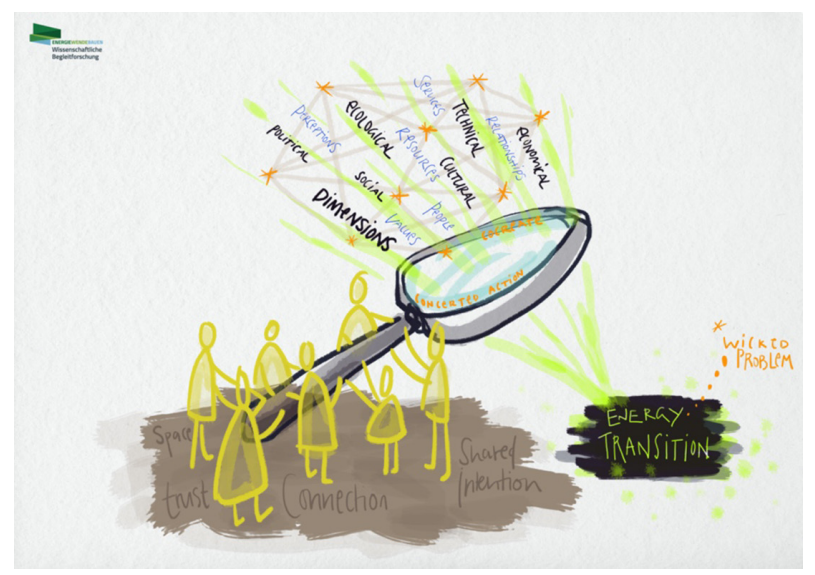

Figure 1: The burning lens of the energy transition - Source: Jana Kottmeier.

Figure 1 stems from the method Generative Scribing, the application of which will be described in Section 6.2. The artwork visualizes how we imagine our work: figuratively speaking we seek to be a burning glass that unites the different ideas, technologies, and disciplines coming together as beams, which pools them into 'concerted action'. What we thrive for is to create 'Communities of Practice' [31] among people working to bring about the energy turnaround in the heat sector. The diversity of stories and perspectives represents the complexity of life, which again lies at the core of sustainability concerns.

Through organizing and planning events like workshops, professional peer-coaching or conferences, we open up possibilities and 'safe spaces', in which the participants are able to communicate and collaborate in different group sizes and settings. Systematically and participatively, we enable new collaborations to emerge and growing collaborations to come to full bloom. We seek to create opportunities for people to meet and move something together. Communication is - metaphorically speaking - the mortar between all the bricks forming the energy transition and our project team intends to help and foster a good and open communication, so that real collaborations can be established.

\section{METHODOLOGY APPLIED IN OUR RESEARCH}

In this section, we present a general overview of a number of concepts and methods that are generally used by organizations (like, e.g. Collaborative Helvetica) and specifically by our research team to foster these transformation processes by collaborative work structures, refer to Table 1. Moreover, one specific method called Generative Scribing will be outlined in detail. Making use of the methods requires stepping out of our personal and disciplinary comfort zone, which is naturally accompanied by resistance at first. That is why a significant amount of courage and time needs to be poured into networking, communicating, and establishing a basis of understanding and mutual acceptance.

\subsection{A brief overview on methods}

A lot of our methodology can be classified as what Scharmer and Käufer refer to as methods used in 'awareness-based action research' [30]. Scharmer with his diverse teams as well as research collaborators has developed a concept called Theory $\mathrm{U}$ that can be understood as a 
Table 1: Toolbox for collaborative communication.

\begin{tabular}{|c|c|c|}
\hline Approaches & $\begin{array}{l}\text { Methods - how the approaches are brought } \\
\text { into practice }\end{array}$ & $\begin{array}{l}\text { Sense and purpose - what } \\
\text { we want to achieve }\end{array}$ \\
\hline $\begin{array}{l}\text { Transfor- } \\
\text { mative } \\
\text { Science }\end{array}$ & $\begin{array}{l}\text { Real-World Labs } \\
\text { Spaces of transdisciplinary as well as participa- } \\
\text { tory and transformative research [33], that per- } \\
\text { form interventions in real-world social contexts } \\
\text { in order 'to achieve a deeper understanding and } \\
\text { the realization of transformations' [28]. }\end{array}$ & $\begin{array}{l}\text { Rather a paradigm shift } \\
\text { than an approach: } \\
\text { Moving from a describ- } \\
\text { ing science to one that } \\
\text { initiates and catalyzes } \\
\text { transformational change } \\
{[29,34] \text {. }}\end{array}$ \\
\hline \multirow[t]{3}{*}{$\begin{array}{l}\text { Collabo- } \\
\text { ratories } \\
\text { based on } \\
\text { the Theory } \\
\text { U }\end{array}$} & $\begin{array}{l}\text { Generative Listening } \\
\text { Opening the will so that one's perspective } \\
\text { merges with the systems' perspectives in a way } \\
\text { that it is leading from the emerging system's } \\
\text { future. 'When that deeper generative field is } \\
\text { activated, we usually experience it as time } \\
\text { slowing down, space opening, widening, the } \\
\text { sense of self decentering, while the self- other } \\
\text { boundary opens up to a collective presence } \\
\text { from which the conversation seems to flow' } \\
\text { [35]. }\end{array}$ & $\begin{array}{l}\text { Enabling generative } \\
\text { social fields by hosting } \\
\text { integrative conversations } \\
\text { between the research } \\
\text { network and the field } \\
\text { actors. Enabling a sense } \\
\text { of 'us' that enables the } \\
\text { participants to co-create, } \\
\text { as it arises through shared } \\
\text { experience and a collec- } \\
\text { tive will }[35,37,38] \text {. }\end{array}$ \\
\hline & $\begin{array}{l}\text { Guided Journaling } \\
\text { A set of questions that provide stimuli for sens- } \\
\text { ing and reflecting about oneself and the system } \\
\text { around. Each member of a group goes through } \\
\text { the predefined questions in its personal space } \\
\text { followed by an exchange in small groups or the } \\
\text { plenum [35]. }\end{array}$ & $\begin{array}{l}\text { Finding the deeper } \\
\text { sources of what we do } \\
\text { and creating intentions for } \\
\text { joint action. }\end{array}$ \\
\hline & $\begin{array}{l}\text { Prototyping } \\
\text { Rapid, co-creative, iterative development of } \\
\text { prototypes that transform the future of the sys- } \\
\text { tem into reality. Alternates with silent phases of } \\
\text { reflection (e.g. journaling) [36]. } \\
\text { 'As we enact prototypes we explore the future } \\
\text { by doing. The relationship between observer } \\
\text { and observed continues its inversion' [13]. }\end{array}$ & $\begin{array}{l}\text { Bringing the predesigned } \\
\text { actions into reality, } \\
\text { experimenting together } \\
\text { what works. }\end{array}$ \\
\hline
\end{tabular}




\begin{tabular}{ll}
\hline Art of & World Café \\
Hosting & Table groups of four to five people are formed \\
[10] [39] & around a common topic. One person is the host \\
& who will be in charge of the table's outcome \\
& for the following three rounds. The topic is \\
& now discussed between the visitors. At the end \\
& of the first round, all table guests except for the \\
& host look for new tables and thus carry on the \\
& dialogs and results. In this way, the subsequent \\
& rounds, which follow the same patterns, are \\
& enriched.
\end{tabular}

enriched.
Since misunderstandings

are the rule and compre-

hension the exception

[40], it is necessary to

create fertile and appre-

ciating spaces in which

good communication

'happens like on its own'.

Art of Hosting is more than a set of methods, it is a mindset, a vehicle for collaboration and the attempt to open up a space for emergence. The World Café is used for deeper reflection on topics we want to move further.

Open Space is meant to bring ideas together and lead them to joint action.

\section{Open Space}

Open Space is defined by the self-organization and freedom and spontaneity of the participants. Topics can be freely introduced by individuals and supervised in the course of the method. Without an own topic, participants move freely. At the end, a protocol for all topics is provided.

\section{Appreciative Inquiry}

Focusing on what works rather than on what does not work - dreams, desires, strengths, passion, and sources. Inclusion of the methodological needs and experience of the participants.

Design Depending on the approach, the design thinkThinking ing process is described as having from three (inspiration, ideation, implementation) [11] to seven steps (define problem, understand problem, define persona, ideate, design prototypes, test prototypes, integrate prototypes) [41], with constant iterations. Divergent and convergent thinking are alternately addressed in the process. Furthermore, each step comes with its own specific methods.
Appreciative Inquiry helps to focus on what is already there instead of what is missing.

Integrating users' stories, perspectives and needs into the (scientific) process. Increasing users' acceptance and participation is targeted [42]. 
framework, a method, and a mindset at the same time [13]. Basically, the form of the U, also serving as the eponym for the theory, visualizes the dynamic road that every single successful group process will ultimately follow (a visualization of this can be found in ref. [32]). It starts with becoming aware of one's own patterns (or those of one's organization, team, etc., as it is originally a management theory), opening them up and letting them go (the left side of the $\mathrm{U}$ ), until at the bottom the system (person, organization, etc.) gets to connect with itself/ themselves. This is the point of connecting, not only with one's own motivation and goals but also with those of other team members and parts of the system. It is where we create the shared sources, motivations, and support in our work within the system of people engaged with the energy transition of the building sector. The right, upcoming part of the U finally is the building of the future, by prototyping new social practices, lifestyles, and sustainable governance structures. Via prototyping, which is part of design thinking inside Theory U, the emerging future can be explored and created together in action. This process enables groups to sense and create the emerging future together and leads to a shift from an ego-system perspective to an eco-system perspective [25]. If such a stage is reached, it is not important who did what, but it leads to the establishment of a mutual feeling of accomplishment - a sense of community and a collective transformation.

\subsection{Helping the emerging future come to live - The application of Generative Scribing}

The method Generative Scribing stems from the so-called scribing, which is a visual practice created in the 1970s in California and has been established by Bird in the context of Theory $\mathrm{U}$ [12]. When practicing scribing during a conference, a conversation, or a meeting, the artist or 'scribe' links topics with the artwork and, e.g. thereby supports decision making [12]. Here primarily the content on the surface is captured by the artwork. This is taken a step further by Generative Scribing as the scope of the scribe is expanded [12]. It is a form of art, a process, a social act 'with which we open to the unknown to bring it to life - of, and for, a social body' [12]. The artwork is the result of a participatory process, in which the scribe 'serves as artistic aid(s) in shared seeing and human navigation' [12]. The scribe is able to voice the different views of the social body within the artwork by sensing non-judgmentally and generatively in the present social field [12]. When applying Generative Scribing, the artist listens on a deep level and makes the essence of what is being said visible [12]. Bird has identified four levels of scribing [12] in relation to the four levels or fields of listening described by Scharmer [13]. For Generative Scribing, it is important to sense with the heart and to work in connection with the source, the inner point guiding our actions [12]. The artwork is a support for the social body to fearlessly tack and, therefore, make changes happen. It has high potential to becoming the basis of a shared intention guiding the social body through challenging times [12].

Typically, the scribe and the artwork of the scribe can be seen by the audience during the process and is, thereby, immediately influencing and transforming the thinking in the room [12]. However, in some settings, it is not possible or useful to do so, e.g. during a conference with differing settings. Bird stresses in her book that Generative Scribing is in fact changing with the changes in the social field and, therefore, the application of the method can vary [12].

The method has been applied in several different meetings since our project has started. Our experiences show that, at first, people tend to be sceptic when the method is applied. However, the artwork that developed during the meeting has always been shown at the end to the attendees to be open for reflection and discussion. Thoughts have been shared, upcoming 
questions were uttered, and, in further consequence, it served as an opportunity to jointly review in retrospect the essence of the meeting. We therefore argue that the application of such methods in a technologically driven social field can softly open the minds for new ways of working towards more collaborative structures as it supports the process of finding a joint intention. Results can be found in ref. [43].

\section{CONCLUSION}

The scientist and Lord Mayor of the 'transformation city' Wuppertal, Uwe Schneidewind, recently created a term for the ability to deal with the complexity of dimensions and the diversity of actors involved in transformation processes: for him this is the Zukunftskunst (roughly translated: the 'art of futurism') [44]. This notion includes some basic principles of our work concerning transformation processes: it needs dedication, space, and moreover time [16]. As a matter of course, we have experienced some setbacks, as naturally most of the resistance towards uncommon methodology (which ours is for most of our system peers), occurs in the beginning [45]. But we have also experienced the impacts of the methods applied when people take their time to accommodate themselves to something new and uncommon. In our own research team, we discovered the effect of truly connecting with each other leading to a feeling of community and power. Altogether, we are deepening our 'sense of the field' [25] and whilst working together, we continuously experience the U process.

\section{ACKNOWLEDGMENTS}

We are very thankful for the inclusion, support, and funding of our project work by the German Federal Ministry for Economic Affairs and Energy (project number: 03EWB001B), and we would like to thank the Projektträger Jülich (project carrier: Jülich) for the great support and guidance. Only the authors are responsible for the content of this paper.

Furthermore, we would like to express our deepest gratitude towards our colleagues in the broader accompanying research network for the energy transition in the German building sector and all grantees for the courage and time they are investing into exploring unknown, uncommon waters. And last but not least, we are thankful to the international U.lab community whom we are part of and feel encouraged by ourselves to support the great transformation urgently needed.

\section{REFERENCES}

[1] German Energy Agency (dena), Building report - Energy efficiency in the building stock - statistics and analyses, 2018, available at https://www.dena.de/fileadmin/dena/ Dokumente/Pdf/9268_dena_concise_2018_building_report.pdf (accessed 08 August 2021).

[2] Energiewendebauen. Forschung für energieoptimierte Gebäude und Quartiere, available at https://www.energiewendebauen.de/startseite (accessed 09 August 2021).

[3] United Nations (UN), Transforming our world: The 2030 Agenda for Sustainable Development, 2015, available at https://sdgs.un.org/sites/default/files/publications/21252030\%20Agenda\%20for\%20Sustainable\%20Development\%20web.pdf (accessed 05 August 2021).

[4] German Advisory Council on Global Change (WBGU), World in Transition - A Social Contract for Sustainability, 2011, available at https://www.wbgu.de/en/publications/publication/world-in-transition-a-social-contract-for-sustainability (accessed 05 August 2021). 
[5] United Nations Development Programme (UNDP). The great transformation, Working with radical uncertainty in a planetary crisis, Web Site, available at https://stories. undp.org/the-great-transformation?utm_source=web\&utm_medium=homepage\&utm_ campaign=greattransformation (accessed 10 August 2021).

[6] Korten, D.C., The Great Turning: From Empire to Earth Community, Berrett-Koehler: San Francisco, 2007.

[7] Polanyi, K., The Great Transformation: The Political and Economic Origins of Our Time, Beacon Press: Boston, MA, 1957.

[8] United Nations (UN), Independent Group of Scientists Appointed by the SecretaryGeneral, Global Sustainable Development Report 2019: The Future Is Now - Science for Achieving Sustainable Development, 2019, available at https://reliefweb.int/sites/ reliefweb.int/files/resources/24797GSDR_report_2019.pdf (accessed 09 August 2021).

[9] Seager, T., Selinger, E. \& Wiek, A., Sustainable engineering science for resolving wicked problems. Journal of Agricultural and Environmental Ethics, 25, pp. 467-484, 2012. https://doi.org/10.1007/s10806-011-9342-2

[10] AoH Team Hamburg. The Art of Hosting \& Harvesting conversations that matter, Online, 2019, available at https://www.einfachgutelehre.uni-kiel.de/wp-content/ uploads/2016/04/Aoh-Hamburg-Handbuch-Final.pdf (accessed 08 August 2021).

[11] Brown, T., Design thinking. Harvard Business Review, 86(6), pp. 84-92, 2008.

[12] Bird, K., Generative Scribing. A Social Art of the 21st Century. Presencing Institute: Cambridge, 2018.

[13] Scharmer, O.C., Theory U: Leading from the Future as It Emerges - The Social Technology of Presencing. Society for Organizational Learning: Cambridge, MA, 2007.

[14] Göpel, M., The great mindshift, how a new economic paradigm and sustainability transformations go hand in hand. The Anthropocene: Politik-Economics-Society-Science, vol. 2, ed. H.G. Brauch, Switzerland: Springer Nature, 2016.

[15] Loorbach, D., Frantzeskaki, N. \& Avelino, F., Sustainability transitions research: transforming science and practice for societal change. Annual Review of Environment and Resources, 42, pp. 599-626, 2017. https://doi.org/10.1146/annurev-environ-102014-021340

[16] Grin, J., Rotmans, J. \& Schot, J., Transitions to sustainable development: new directions in the study of long-term transformative change. Routledge Studies in Sustainability Transitions, Routledge: New York, 2010.

[17] Geels, F.W., The multi-level perspective on sustainability transitions: responses to seven criticisms. Elsevier Environmental Innovation and Societal Transitions, 1, pp. 24-40, 2011. https://doi.org/10.1016/j.eist.2011.02.002

[18] Meadows, D., Leverage Points: Places to Intervene in a System. The Sustainability Institute: Hartland, VT, 1999.

[19] Geels, F., McMeekin, A., Mylan, J. \& Southerton, D., A critical appraisal of sustainable consumption and production research: the reformist, revolutionary and reconfiguration positions. Global Environmental Change, 34, pp. 1-12, 2015. https://doi.org/10.1016/j. gloenvcha.2015.04.013

[20] Göpel, M., Hermelingmeier, V., Kehl, K., Then, V., Vallentin, D. \& Wehnert, T., System innovation lab: shaping Europe's energy future, 2016, available at https://epub.wupperinst.org/frontdoor/deliver/index/docId/6538/file/6538_System_Innovation_Lab.pdf (accessed 14 May 2021). 
[21] Abercrombie, R., Harris, E. \& Wharton, R., New Philanthropy Capital (NPC), Systems Change, A Guide to What It Is and How to Do It. Lankelly Chase: UK, 2015.

[22] Kurt, H., Wachsen! Über das Geistige in der Nachhaltigkeit. Verlag Bild-Kunst: Bonn, 2010.

[23] Harding, S., Animate Earth. Science, Intuition and Gaia. Green Books: Cambridge, 2009.

[24] Merkel, W., Brückner, J., Wagener, H.J. \& Teil II, Theoretische Paradigmen, System. Handbuch Transformationsforschung, eds. R. Kollmorgen, W. Merkel \& H.J. Wagener, Springer: Wiesbaden, 2015.

[25] Nanz, P., Handbuch Bürgerbeteiligung. Verfahren und Akteure, Chancen und Grenzen. Bundeszentrale für politische, Bildung: Bonn, 2012.

[26] Schweizer-Ries, P. \& Perkins, D.D., Sustainability science: transdisciplinarity, transepistemology, and action research. Umweltpsychologie, 16(1), pp. 6-10, 2012.

[27] Iser, O., Schüren, A. \& Schweizer-Ries, P., Bewusstseinsbasierte, transformative Nachhaltigkeitswissenschaft. Nachhaltigkeit in den Sozialwissenschaften, Theorie und Praxis der Nachhaltigkeit, ed. W. Leal Filho, Springer Nature, in press.

[28] Schneidewind, U., Singer-Brodowski, M., Augenstein, K. \& Stelzer, F., Pledge for a Transformative Science, Wuppertal Paper, no. 191, July 2016.

[29] Schneidewind, U., Transformative Wissenschaft - Motor für gute Wissenschaft und lebendige Demokratie. GAIA, 24(2), pp. 88-91, 2015. https://doi.org/10.14512/gaia.24.2.5

[30] Scharmer, C.O. \& Käufer, K., Awareness-based action research: catching social reality creation in flight. The SAGE Handbook of Action, ed. H. Bradbury. Sage Publications: London, pp. 199-210, 2015.

[31] Wenger, E., Communities of practice: a brief introduction. STEP Leadership Workshop. University of Oregon: Oregon, pp. 1-7, 2011.

[32] Presencing Institute. available at https://www.presencing.org/aboutus/theory-u (accessed 09 August 2021).

[33] Wanner, M., Stelzer Dr., F., Reallabore Perspektiven für ein Forschungsformat im Aufwind. Wuppertaler Impulse zur Nachhaltigkeit. Wuppertal Institut: Wuppertal, 2019.

[34] Defila, R. \& Di Giulio, A., eds., Transdisziplinär und transformativ forschen. Eine Methodensammlung. Springer Nature: Berlin, 2018.

[35] Guided Journaling; Presencing Institute, available at https://www.presencing.org/ resource/tools/guided-journaling-desc (accessed 09 August 2021).

[36] Protoyping; Presencing Institute, available at https://www.presencing.org/resource/ tools/prototyping-descavailable (accessed 08. August 2021).

[37] Muff, K., Five Superpowers for Co-Creators. How Change Makers and Business Can Achieve the Sustainable Development Goals. Routledge: London, 2019.

[38] Fein, E. et al., LiFT Methodology Book. Designing and Hosting Collaboratories, 2018, available at http://leadership-for-transition.eu/?page_id=629 (accessed 10 August 2021).

[39] Evangelical Academy Bad Boll, Art of Hosting: Die Kunst, Räume für gute Gespräche $z u$ schaffen, 2016, available at https://christophweinmann.de/aoh-handbuch-badboll2016.pdf (accessed 08 August 2021).

[40] Watzlawick, P., et al., Menschliche Kommunikation. Hans Huber-Verlag: Bern, 2000.

[41] Schallmo, D.R.A. \& Lang, K., Design Thinking erfolgreich anwenden. So entwickeln Sie in 7 Phasen kundenorientierte Produkte und Dienstleistungen. Springer Gabler: Wiesbaden, 2020. 
[42] Alexandrakis, J., Cycling towards sustainability: the transformative potential of urban design thinking in a sustainable living lab. Transportation Research Interdisciplinary Perspectives, 9, 100269, 2021.

[43] https://www.hochschule-bochum.de/fbe/fachgebiete/energiewendebauen-mondowi/

[44] Schneidewind, U., Die Große Transformation. Eine Einführung in die Kunst gesellschaftlichen Wandels. Fischer: Frankfurt a.M., 2018.

[45] Pardo-del-Val, M. \& Martinez-Fuentes, C., Resistance to change: a literature review and empirical study. Management Decision, 41(2), pp. 148-155, 2003. https://doi. org/10.1108/00251740310457597 